\title{
xxIU congresso de iniciação científica da unicamp

\section{PERFIL CLÍNICO E EPIDEMIOLÓGICO DAS INFECÇÕES DO SISTEMA NERVOSO CENTRAL DIAGNOSTICADAS NA UNIDADE DE EMERGÊNCIA PEDIÁTRICA DA UNICAMP}

\author{
Mariana Chiaradia Dominguez*, Dr. Ricardo Mendes Pereira
}

\section{Resumo}

As infecções que acometem o Sistema Nervoso Central (SNC) podem se apresentar na forma de meningite, mielite ou meningoencefalite. Se não forem diagnosticadas e tratadas adequadamente, podem causar elevada morbimortalidade, com déficits motores e cognitivos, retardo neuropsicomotor, distúrbios de comportamento e convulsões. A análise do líquor cefalorraquidiano (LCR) apresenta grande importância no diagnóstico e acompanhamento dessas infecções. O objetivo desse estudo é avaliar as condições que mais frequentemente levaram à realização de coleta de LCR na Unidade de Emergência Referenciada da Unicamp (UER-Unicamp), além de levantar dados epidemiológicos sobre as infecções confirmadas e o perfil clínico dos pacientes que foram submetidos ao procedimento. Trata-se de um estudo transversal e retrospectivo, que analisou fichas de atendimento de pacientes menores de 14 anos na UER PediátricaUnicamp e resultados das análises de LCR dos pacientes.

\section{Palavras-chave:}

Infecções, Sistema Nervoso Central , Pediatria

\section{Introdução}

A maior parte dos quadros de meningite é causada por bactérias ou vírus. A meningite bacteriana tem como principais agentes etiológicos $\mathrm{O} \mathrm{H}$. influenzae, o $\mathrm{S}$. pneumoniae e a N. meningitidis. A redução dos casos de meningites causados por bactérias, devido ao uso das vacinas, levou a uma alteração na epidemiologia da doença, com o aumento na proporção dos casos de meningite viral. Os principais vírus relacionados à meningite são: enterovirus, herpes vírus tipo 6 e parechovirus. A análise do LCR apresenta grande valor para o diagnóstico e tratamento das infecções do SNC. Na maioria dos casos, a punção pode ser realizada sem riscos. Dos casos de meningite notificados em 2015 no estado de SP, aproximadamente $58 \%$ ocorreram na faixa etária abaixo de 14 anos.

Métodos: Foram incluídos na pesquisa pacientes menores de 14 anos submetidos à punção de LCR na UERPediatria. $O$ trabalho foi realizado por meio da coleta de informações à respeito da análise do LCR. A coleta dos dados clínicos foi realizada por meio da revisão dos prontuários e fichas de atendimento. Em seguida, as informações foram transcritas para uma planilha específica no Excel, para posterior análise.

\section{Resultados e Discussão}

No período compreendido pelo estudo, foram colhidas 82 amostras de LCR na UER Pediátrica-Unicamp. Desse total, foi possível analisar os prontuários de 55 pacientes. Os seguintes dados foram obtidos a partir dos prontuários, sendo representados nas tabelas as informações que apresentaram maior frequência:

\begin{tabular}{|l|c|c|}
\hline \multicolumn{1}{|c|}{$\begin{array}{c}\text { Sintoma no Pronto } \\
\text { Atendimento }\end{array}$} & $\mathbf{n}$ & $\%$ \\
\hline Febre & 24 & 43,63 \\
\hline Convulsão & 7 & 12,72 \\
\hline Cefaleia & 6 & 10,90 \\
\hline Vômitos & 6 & 10,90 \\
\hline $\begin{array}{c}\text { Hipótese Diagnóstica } \\
\text { Inicial }\end{array}$ & $\mathbf{n}$ & $\%$ \\
\hline Meningite/meningoencefalite & 21 & 38,18 \\
\hline Febre a/e & 8 & 14,54 \\
\hline Crise convulsiva a/e & 6 & 10,90 \\
\hline
\end{tabular}

\begin{tabular}{|l|c|c|}
\hline \multicolumn{1}{|c|}{ Diagnóstico final } & $\mathbf{n}$ & $\%$ \\
\hline $\begin{array}{l}\text { Meningite/meningoencefalite } \\
\text { viral }\end{array}$ & 13 & 23,63 \\
\hline Meningite bacteriana & 6 & 10,9 \\
\hline Síndrome convulsiva & 5 & 9,09 \\
\hline
\end{tabular}

A idade média dos pacientes foi de 3 anos e 5 meses. Dos pacientes incluídos na pesquisa, 43 eram do sexo masculino e 39 do sexo feminino. Os seguintes microorganismos foram encontrados nas culturas positivas: S. pneumoniae (1), S. epidermidis (1), N. meningitidis (1).

Inicialmente, 21 pacientes tiveram suspeita infecção do SCN (meningite/meningoencefalite), e destes, 13 tiveram o diagnóstico confirmado.

A análise do LCR de todos os pacientes com infecção confirmada apresentou as seguintes características:

\begin{tabular}{|l|c|c|c|}
\hline Característica & $\mathbf{n}$ & Média & $\begin{array}{c}\text { Desvio } \\
\text { Padrão }\end{array}$ \\
\hline Proteína & 19 & 74,26 & 99,50 \\
\hline Gicose & 19 & 59,10 & 24,44 \\
\hline Leucócitos & 19 & 1179,2 & 2320,34 \\
\hline Hemácias & 19 & 6062,94 & 22295,69 \\
\hline
\end{tabular}

\section{Conclusões}

A realização da coleta de LCR e sua posterior análise são indicadas a partir da história clínica e exame do paciente. Queixas como febre e cefaleia, quando associadas com outros sinais clínicos, como abaulamento de fontanela e rigidez nucal, presente em alguns dos pacientes inclusos no estudo levam, dentre outras hipóteses, à suspeição de quadros de infecção do SNC, especialmente as meningites. Conforme esperado, foram registrados mais casos de meningite viral em comparação à bacteriana, mas a análise do LCR também foi necessária para excluir possíveis infecções e direcionar para outros diagnósticos.

\section{Agradecimentos}

Agradeço ao meu orientador, Dr. Ricardo Mendes Pereira, por todo apoio e dedicação para que o trabalho fosse possível, ao Dr. Marcelo Reis e à UER-Pediatria pela disponibilização dos arquivos necessários. O projeto contou com apoio do Pibic-CNPq. 